\title{
Structural Characterization of G-Quadruplexes in Deoxyguanosine Clusters Using Ion Mobility Mass Spectrometry
}

\author{
Erin Shammel Baker, Summer L. Bernstein, and Michael T. Bowers \\ Department of Chemistry and Biochemistry, University of California, Santa Barbara, California, USA
}

The aggregation and conformation of deoxyguanosine $(\mathrm{dG})$ in an ammonium acetate buffer solution were examined using mass spectrometry, ion mobility, and molecular mechanics/ dynamics calculations. The nano-ESI mass spectrum indicated that 4 and $6 \mathrm{dGs}$ cluster with 1 $\mathrm{NH}_{4}{ }^{+}$; $11 \mathrm{dGs}$ with $2 \mathrm{NH}_{4}{ }^{+} ; 14,16$, and $17 \mathrm{dGs}$ with $3 \mathrm{NH}_{4}{ }^{+}$; and $23 \mathrm{dGs}$ with $4 \mathrm{NH}_{4}{ }^{+}$. The collision cross sections with helium were measured and compared with calculated cross sections of theoretical structures generated by molecular mechanics/dynamics calculations. Three distinct arrival time distribution (ATD) peaks were observed for $\left(4 \mathrm{dG}+\mathrm{NH}_{4}\right)^{+}$. One peak was assigned to the quadruplex structure of $\left(4 \mathrm{dG}+\mathrm{NH}_{4}\right)^{+}$, while the other two peaks corresponded to the quadruplex structures of $\left(8 \mathrm{dG}+2 \mathrm{NH}_{4}\right)^{2+}$ and $\left(12 \mathrm{dG}+3 \mathrm{NH}_{4}\right)^{3+}$, all with the same $\mathrm{m} / \mathrm{z}$. Four ATD peaks were observed for $\left(6 \mathrm{dG}+\mathrm{NH}_{4}\right)^{+}$and assigned to the globular structure of $\left(6 \mathrm{dG}+\mathrm{NH}_{4}\right)^{+}$, and the quadruplex structures of $\left(12 \mathrm{dG}+2 \mathrm{NH}_{4}\right)^{2+},(18 \mathrm{dG}+$ $\left.3 \mathrm{NH}_{4}\right)^{3+}$, and $\left(24 \mathrm{dG}+4 \mathrm{NH}_{4}\right)^{4+}$. Two ATD peaks were observed for $\left(11 \mathrm{dG}+2 \mathrm{NH}_{4}\right)^{2+}$ and assigned to the quadruplex structures of $\left(11 \mathrm{dG}+2 \mathrm{NH}_{4}\right)^{2+}$ and $\left(22 \mathrm{dG}+4 \mathrm{NH}_{4}\right)^{4+}$. All of the other clusters in the mass spectrum $\left(14,16\right.$, and $17 \mathrm{dGs}$ with $3 \mathrm{NH}_{4}{ }^{+}$and $23 \mathrm{dGs}$ with $\left.4 \mathrm{NH}_{4}{ }^{+}\right)$ only had one peak in their ATDs and in all cases the theoretical structures in a quadruplex arrangement agreed with the experimental cross sections. These results provide compelling evidence that quadruplexes are present in solution and retain their structure during the spray process, dehydration, and detection. (J Am Soc Mass Spectrom 2005, 16, 989-997) ( 2005 American Society for Mass Spectrometry

$\mathrm{T}$ The stability and structure of DNA complexes is an area of great interest. For years after Watson and Crick proposed the DNA helix, many scientists accepted the idea that DNA was a very uniform molecule where two antiparallel strands were held together by Watson-Crick base pairs to form a right-handed helix. However, a number of NMR and X-ray crystallography studies [1] have illustrated that a wide variety of secondary DNA structures exist. In fact, hairpins [2], cruciforms [3], guanine quadruplexes [4, 5], and lefthanded helices $[6,7]$ are just a few examples of alternative DNA conformations.

One DNA secondary structure of great interest is the guanine quadruplex or G-quadruplex [4, 5]. G-quadruplexes are made up of G-quartet subunits, where 4 coplanar guanines $(\mathrm{G})$ are linked together by Hoogsteen hydrogen bonds (Scheme 1). When the G-quartets stack on top of each other, they form the G-quadruplex, which is very stable and important in DNA sequences that are purine rich and contain runs of G. Recently,

Published online May 23, 2005

Address reprint requests to Dr. M. T. Bowers, Department of Chemistry and Biochemistry, University of California, Santa Barbara, CA 931069510, USA. E-mail: bowers@chem.ucsb.edu interest in G-quadruplex structures has increased greatly because of the many G-rich biologically significant genome regions including the immunoglobulin switch regions [8], gene promoter regions [9], sequences associated with various human diseases [10], and the end of chromosomes (telomeres) [11]. Having accessibility to so many G-rich biological sequences has prompted the idea of using G-quadruplexes as therapeutic agents and targets for anticancer drug design in G-rich regions $[12,13]$. Thus, understanding G-quadruplex interactions is essential in order to design a drug that will bind correctly and effectively.

Electrospray ionization mass spectrometry (ESI-MS) is a very important technique for the characterization of biological molecules in the gas phase [14-16]. By gently transferring ions from solution phase to gas phase, the soft ionization process of ESI has proven to be invaluable for studying the noncovalent interactions of biomolecules [17-21]. Recently, ESI-MS studies have illustrated that G-quadruplex stoichiometries exist in the gas phase, indicating that there may be a level of solution phase structure conservation. Several mass spectrometry papers have reported "magic number" quartet adducts of guanine and guanosine [22-24], Goodlett et al. have observed $\mathrm{dCGCG}_{5} \mathrm{CG}$ tetramers 


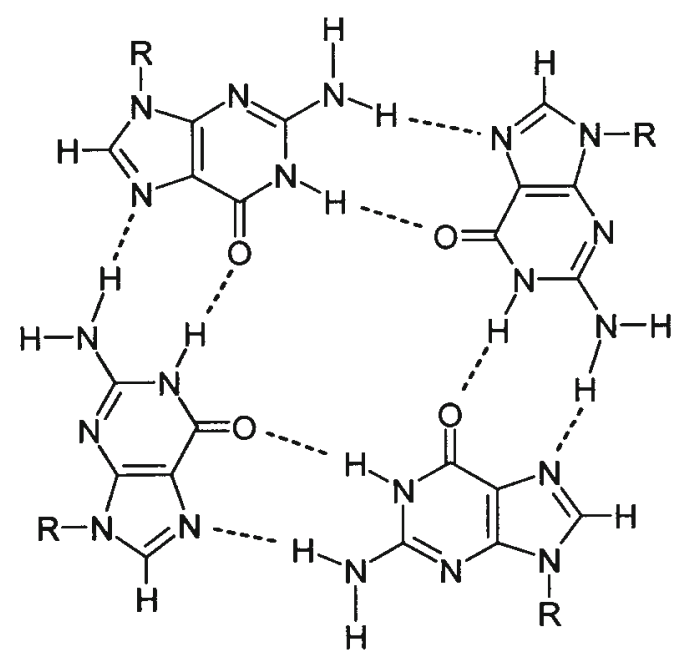

Scheme 1. G-quartet.

[25], and Rosu et al. have detected tetramers of $\mathrm{dTG}_{4} \mathrm{~T}$ [26]. Although these studies show that stoichiometries indicative of G-quadruplexes exist in the gas phase, the overall conformation of each stoichiometry observed still remains a question.

In this paper, we address the issue of whether Gquadruplexes are obtained in the gas phase by reporting on the gas phase clustering and conformational properties of deoxyguanosine (dG) (Scheme 2) with $\mathrm{NH}_{4}{ }^{+}$using nano-ESI-MS, ion mobility [27, 28] and molecular modeling methods. Deoxyguanosine was used in this study because of its small size and lack of a phosphate backbone. By addressing how small guanine containing molecules like dG behave, it will be easier to later evaluate the properties of larger guanine containing molecules like the telomere repeat dTTAGGG.

\section{Experimental}

dG was purchased from Sigma (St. Louis, MO), used without further purification, and resuspended at a concentration of $300 \mu \mathrm{M}$ in a $150 \mathrm{mM} \mathrm{NH} \mathrm{N}_{4} \mathrm{OAc} / \mathrm{H}_{2} \mathrm{O}$ solution at $\mathrm{pH}$ 7. The solution was then annealed at $80^{\circ} \mathrm{C}$ for $10 \mathrm{~min}$, slowly cooled to room temperature, and stored at $10^{\circ} \mathrm{C}$. Before use with nano-ESI, the solution was diluted in half with $\mathrm{H}_{2} \mathrm{O}$, so that dG had a final concentration of $150 \mu \mathrm{M}$.

The details concerning the experimental setup for the mass spectra and ion mobility measurements have been published previously [29], so only a brief description will be given. To obtain a mass spectrum, approximately $6 \mu \mathrm{L}$ of the $150 \mu \mathrm{M}$ dG solution was placed in a metalized glass needle (spray tip). Ions were formed by nano-ESI and a continuous beam was injected into a specially designed ion funnel. The ion funnel acts as an interface between the source and high vacuum chamber and also compresses the stream of ions leaving the capillary. This allows the ions to be transported to the drift cell without the aid of high acceleration fields, avoiding high energy ion-neutral collisions. After exiting the ion funnel, the ions are gently injected into a 4 -cm long drift cell filled with $\sim 5$ torr of helium gas. A weak, uniform electric field across the cell gently pulls the ions through the $\mathrm{He}$ gas at a constant drift velocity. After exiting the drift cell, the ions are gently accelerated through a quadrupole mass filter, which is set to select the mass range of interest in order to acquire a mass spectrum.

In the ion mobility experiments, a pulsed beam of ions is needed and can be acquired using the ion funnel. By raising the potential of the last lenses in the funnel, the ions become trapped. Periodically, the potential is lowered for $10 \mu \mathrm{s}$, and a pulse of ions is released. The injection energy of the ions into the drift cell can be varied from 0 to $150 \mathrm{eV}$. At low injection energies, the ions are gently pulsed into the cell and only need a few "cooling" collisions to reach thermal equilibrium with the buffer gas. However, at high injection energies, the larger collision energy leads to internal excitation of the ions before cooling, and equilibrium occurs. This transient internal excitation can lead to isomerization to the most stable conformers or dissociation of dimers and higher-order oligomers if they are present.

Once the pulsed ions enter the cell, they are quickly thermalized by collisions with $\sim 5$ torr helium buffer gas and are gently pulled through the drift cell by the weak electric field. After exiting the drift cell, the ions enter the quadrupole which is set to a specific mass-to-charge ratio $(\mathrm{m} / \mathrm{z})$ to eliminate any ions that might arise from fragmentation in the drift cell and interfere with the ion mobility experiments. The pulsed voltage of the ion funnel triggers a timing sequence so that the ions are detected as a function of time, yielding an arrival time distribution or ATD. The reduced mobility, $K_{o}$ of the ion is accurately determined from a series of ATDs measured at different electric field strengths $(10-23 \mathrm{~V} / \mathrm{cm})$ across the drift cell. Through the use of kinetic theory, the ion's collision cross section can also be calculated.

\section{Data Analysis}

The reduced mobility of the mass-selected ions can be obtained from the ATD using eq 1 [30]

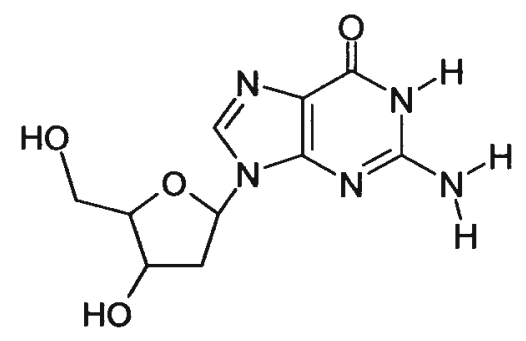

Scheme 2. Deoxyguanosine. 


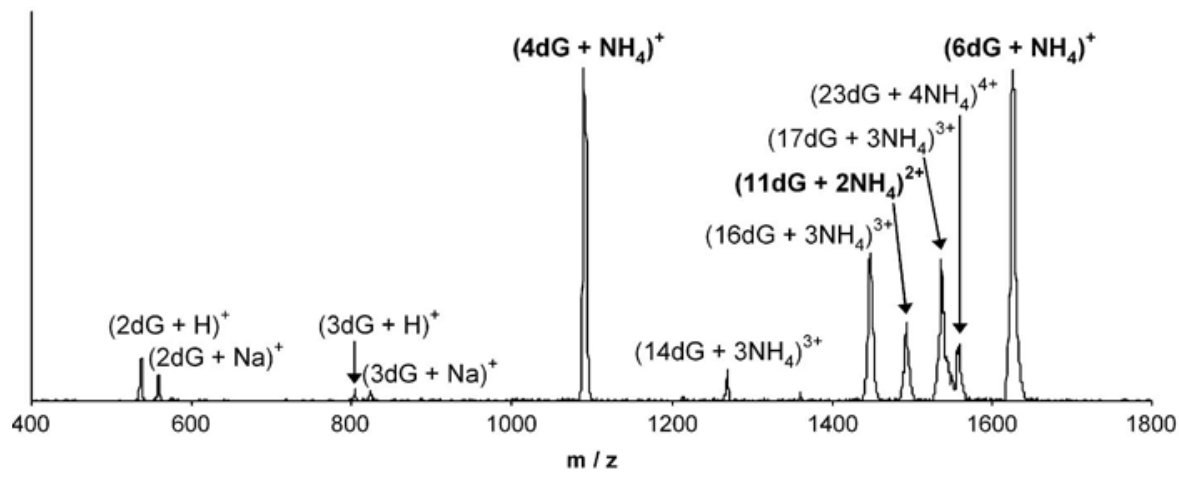

Figure 1. ESI mass spectrum of $\mathrm{dG}$ doped with ammonium; $\mathrm{dG}$ clusters from $\left(4 \mathrm{dG}+\mathrm{NH}_{4}\right)^{+}$to $\left(23 \mathrm{dG}+4 \mathrm{NH}_{4}\right)^{4+}$ are observed. Clusters which have more than one peak in the ion mobility experiments are shown in bold.

$$
K_{o}=\left(l^{2} \cdot \frac{273}{760 T} \cdot \frac{p}{V} \cdot \frac{1}{t_{A}-t_{o}}\right)
$$

where $l$ is the length of the cell, $T$ is the temperature in Kelvin, $p$ is the pressure of the He gas (in torr), $V$ is the voltage, $t_{A}$ is the ions' arrival time taken from the center of the ATD peak and $t_{o}$ is the amount of time the ion spends outside the drift cell before reaching the detector. A series of arrival times are measured by changing the voltage applied to the drift cell. A plot of $t_{A}$ versus $p / V$ yields a straight line with a slope inversely proportional to $K_{o}$ and an intercept of $t_{o}$. Once $K_{o}$ is found, the ion's collision cross section, $\sigma$, can be obtained using eq 2

$$
\sigma=\frac{3 e}{16 N_{o}}\left(\frac{2 \pi}{\mu k_{b} T}\right)^{1 / 2} \frac{1}{K_{o}}
$$

where $e$ is the charge of the ion, $N_{o}$ is the number density of He at STP, $T$ is temperature, $k_{b}$ is Boltzmann's constant, and $\mu$ is the ion-He reduced mass [30].

\section{Theoretical Modeling}

Conformational analysis of the ions is obtained by comparing the experimental cross section from ATDs to the cross sections of theoretical structures. Theoretical starting geometries where the dGs are arranged in a quadruplex structure were created using Hyperchem [31] and then analyzed with AMBER 7 [32] to generate candidate structures for each dG cluster. We have had success in using the AMBER set of molecular mechanics/dynamics programs to provide reliable structures for many small nucleotides systems [33-35]. In these cases, the theoretical cross sections agree well with the ion mobility data.

An annealing/energy minimization cycle is used to generate 200-300 structures for each cluster. In this cycle, an initial minimization of the structure is followed by $30 \mathrm{ps}$ of molecular dynamics at $600 \mathrm{~K}$ and 10 ps of molecular dynamics in which the temperature is incrementally dropped to $50 \mathrm{~K}$. The resulting structure is then energy-minimized again and used as the starting structure for the next minimization/dynamics run. After all low-energy structures are obtained, theoretical cross sections must be calculated for comparison with experimental cross sections. For ions with less than 200 atoms, the angle-averaged collision cross section of each structure is calculated using a temperature-dependent projection model with appropriate atomic collision radii calculated from the ion-He interaction potential [36, 37]. For larger ions, collision cross sections of each structure are calculated using hard-sphere scattering and trajectory models developed by the Jarrold group $[38,39]$. A scatter plot of cross section versus energy is collected for the minimized structures and the average cross section of the lowest $5-10 \mathrm{kcal} / \mathrm{mol}$ structures are then compared with the experiment.

\section{Results and Discussion}

\section{Mass Spectra}

A typical nano-ESI mass spectrum for $\mathrm{dG}$ in ammonium acetate is shown in Figure 1. The two dominant peaks in the mass spectrum correspond to $\mathrm{m} / \mathrm{z}$ values of 4 and 6 dGs with $1 \mathrm{NH}_{4}{ }^{+}$, where the $\left(4 \mathrm{dG}+\mathrm{NH}_{4}\right)^{+}$peak corresponds to the "magic number" peak which has previously been observed in other ESI-MS studies [2226]. Other larger $\mathrm{dG}$ clusters are also observed in the mass spectrum and correspond to $11 \mathrm{dGs}$ with $2 \mathrm{NH}_{4}{ }^{+}$; 14, 16, and $17 \mathrm{dGs}$ with $3 \mathrm{NH}_{4}{ }^{+}$; and $23 \mathrm{dGs}$ with 4 $\mathrm{NH}_{4}{ }^{+}$.

\section{Ion Mobility}

In order to examine the conformational properties and determine whether the $\mathrm{dG}$ clusters with ammonium have a G-quadruplex arrangement, each ion was analyzed with ion mobility. In each case, the appropriate ion was gently injected into the drift cell and its ATD collected. 


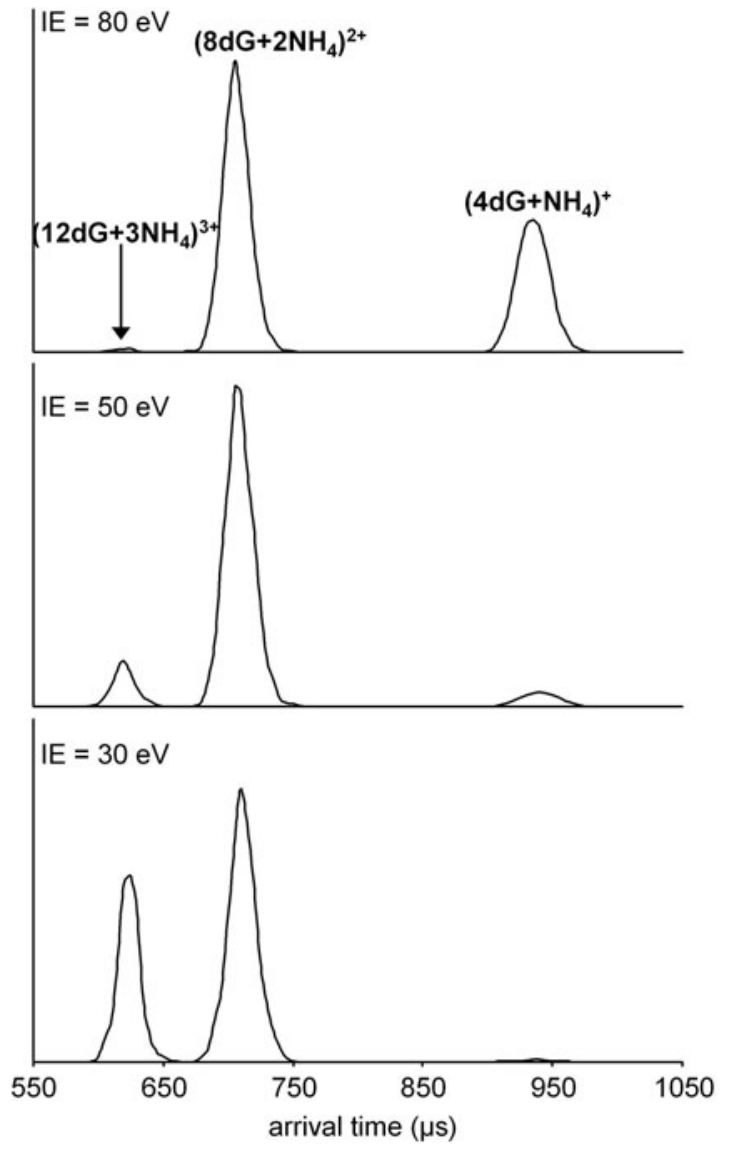

Figure 2. Arrival time distributions (ATDs) for $\left(4 \mathrm{dG}+\mathrm{NH}_{4}\right)^{+}$ measured at different injection energies. Three peaks occur for all three injection energies and are assigned to $\left(4 \mathrm{dG}+\mathrm{NH}_{4}\right)^{+},(8 \mathrm{dG}$ $\left.+2 \mathrm{NH}_{4}\right)^{2+}$, and $\left(12 \mathrm{dG}+3 \mathrm{NH}_{4}\right)^{3+}$ by comparing the experimental and theoretical cross sections. As IE is increased, the abundance of $\left(12 \mathrm{dG}+3 \mathrm{NH}_{4}\right)^{3+}$ decreases because it is broken into $(4 \mathrm{dG}+$ $\left.\mathrm{NH}_{4}\right)^{+}$and $\left(8 \mathrm{dG}+2 \mathrm{NH}_{4}\right)^{2+}$.

$\left(4 d \mathrm{G}+\mathrm{NH}_{4}\right)^{+}$. Arrival time distributions for the cluster of $4 \mathrm{dGs}$ with $1 \mathrm{NH}_{4}{ }^{+}$are shown in Figure 2. All of the ATDs were obtained under similar experimental conditions except injection energy which was set at a low, intermediate, and high voltage. Three peaks are observed for all of the ATDs, but the abundance of each peak changes with injection energy. The peaks at 610 and $700 \mu$ s dominate the lowest injection energy $(30 \mathrm{eV})$ ATD, but as the injection energy is raised the peak at $610 \mu$ s becomes only a minor feature, while the peak at $930 \mu \mathrm{s}$ becomes much more abundant. Since multiple peaks are observed in the ATDs, either multiple conformations or aggregates occur in the experiment. The cross section of each peak was measured yielding 150 $\AA^{2}$ for the shortest time peak, $186 \AA^{2}$ for the intermediate peak, and $288 \AA^{2}$ for the longest time peak (assuming all peaks correlate to the +1 ion).

Theoretical modeling was utilized to determine the conformation of each peak observed in the ATDs. Two hundred low-energy structures were generated for $\left(4 \mathrm{dG}+\mathrm{NH}_{4}\right)^{+}$in a G-quartet arrangement. The angleaveraged collision cross section of each structure was calculated using methods described in the Experimental section and a cross section versus energy plot was then used to help identify the ions observed in the ATDs. The scatter plot of cross section versus energy for ( $4 \mathrm{dG}$ $\left.+\mathrm{NH}_{4}\right)^{+}$starting as a G-quartet is shown in Figure 3. Two distinct families of structures that differ in cross section occur in the scatter plot. The lowest-energy family of structures has an average cross section of 227 $\AA^{2}$ where the dGs are not in a G-quartet, but are a globular or random formation. The other family of structures, $10 \mathrm{kcal} / \mathrm{mol}$ higher in energy, has an average cross section of $291 \AA^{2}$, and in this family the $4 \mathrm{dGs}$ are arranged in a G-quartet with the $\mathrm{NH}_{4}{ }^{+}$placed right above the quartet, hydrogen bonding to the guanine oxygens (as shown in Figure 4).

The three ATD peaks for $(4 \mathrm{dG}+\mathrm{NH} 4)^{+}$were analyzed to determine if any of the observed peaks correspond to the globular or G-quartet families. The peak at $930 \mu$ s has an experimental cross section of 288 $\AA^{2}$, which agrees very well with the cross section calculated for the G-quartet. However, the two shortest time peaks with cross sections of $150 \AA^{2}$ and $186 \AA^{2+}$ do not match the cross section of the globular structure $\left(227 \AA^{2}\right)$, indicating that the globular structure is not present in the experiment. This brings forth an interesting question: What structures actually correspond to the two shortest time peaks in the ATDs?

The injection energy dependence of $\left(4 \mathrm{dG}+\mathrm{NH}_{4}\right)^{+}$ suggests that the peaks at shorter times in the ATD could be aggregates of the single G-quartet peak at 930 $\mu \mathrm{s}[19,40,41]$. From eqs 1 and 2 , we see that

$$
t_{A}=\text { Const } \frac{\sigma}{e}+t_{o}
$$

where Const is a collection of constants or known parameters. Hence,

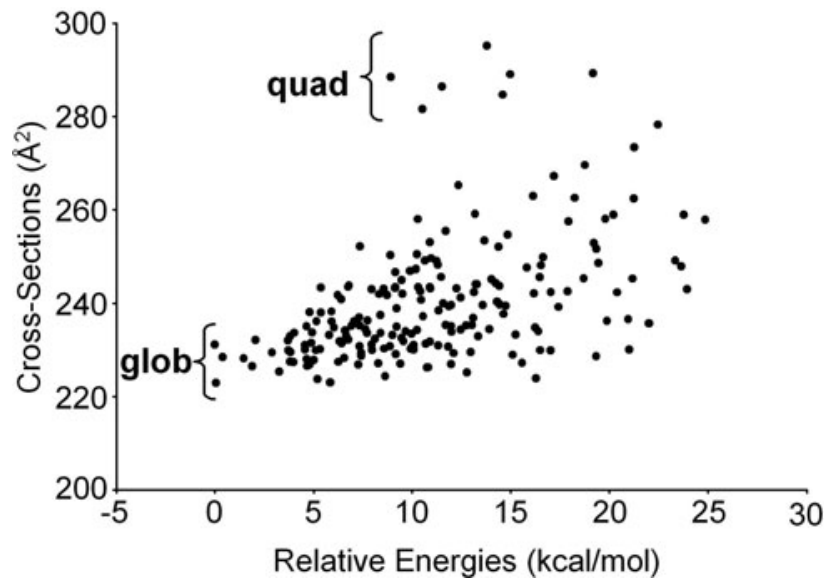

Figure 3. The scatter plot of cross section versus energy for (4dG $\left.+\mathrm{NH}_{4}\right)^{+}$beginning molecular mechanics/dynamics calculations in a G-quartet arrangement. Two families of structures corresponding to a globular and G-quartet form are observed in the scatter plot. 
Top View

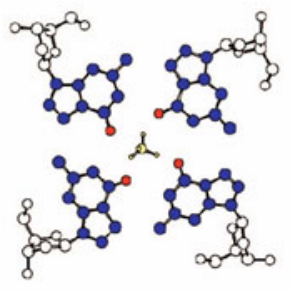

Side View

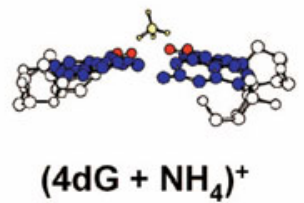

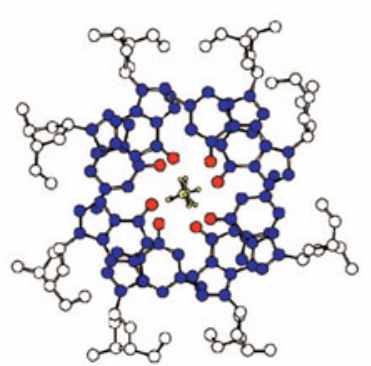
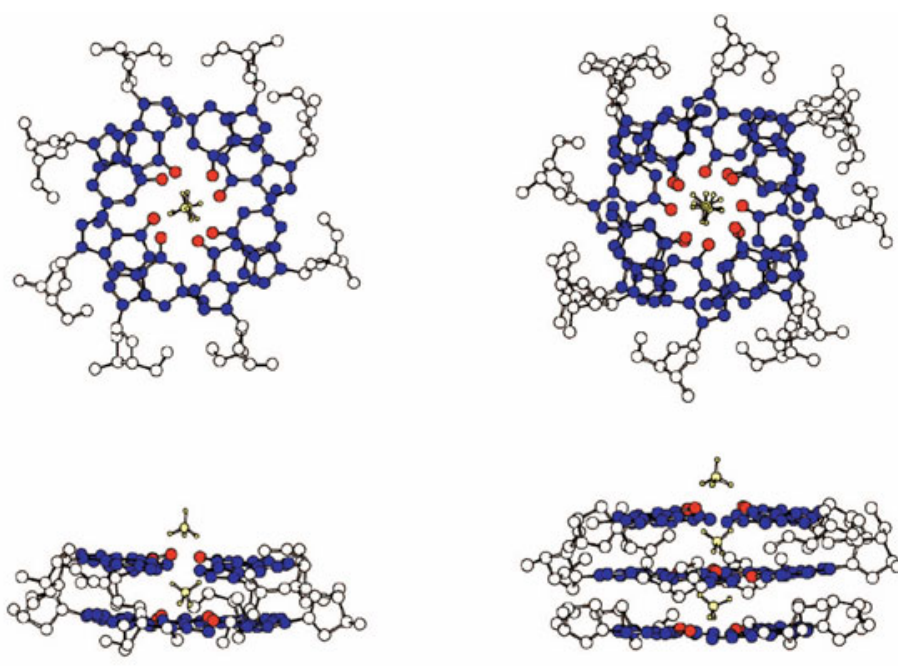

$\left(8 \mathrm{dG}+2 \mathrm{NH}_{4}\right)^{2+}$

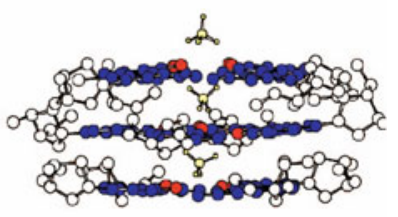

$\left(12 \mathrm{dG}+3 \mathrm{NH}_{4}\right)^{3+}$

Figure 4. The side and top view of the quadruplex theoretical structures for $\left(4 \mathrm{dG}+\mathrm{NH}_{4}\right)^{+},(8 \mathrm{dG}+$ $\left.2 \mathrm{NH}_{4}\right)^{2+}$, and $\left(12 \mathrm{dG}+3 \mathrm{NH}_{4}\right)^{3+}$ which correspond to the three peaks in the ATDs in Figure 2 . The guanine oxygen atom is red, guanines are blue, ammonium is yellow, and sugars are shown in white (hydrogen atoms on each $\mathrm{dG}$ have been omitted for clarity).

$$
t_{A}(M)-t_{A}(D)=\frac{\text { Const }}{e(M)}\left[\sigma(M)-\frac{\sigma(D)}{2}\right]
$$

and the only way that $t_{A}(M)=t_{A}(D)$ is if $\sigma(M)=$ $\sigma(D) / 2$, where $M$ represents a monomer with charge $e(M)$ and $D$ a dimer with charge $2 e(M)$. However, for all real systems $\sigma(M)>\sigma(D) / 2$ resulting in $t_{A}(M)>t_{A}(D)$. This becomes obvious if you realize the maximum cross section for a dimer occurs when the monomer subunits are fully separated and only in this limit does $\sigma(M)=$ $\sigma(D) / 2$. As they come closer together, $\sigma(D) / 2$ becomes smaller until the final dimer structure is obtained. This same argument indicates that the trimer with charge $3 e(M)$ must arrive at the detector before the dimer and so forth for higher aggregates. Hence, the two peaks at shorter time than the $\left(4 \mathrm{dG}+\mathrm{NH}_{4}\right)^{+}$peak at $930 \mu \mathrm{s}$ could be due to aggregates of $\left(4 \mathrm{dG}+\mathrm{NH}_{4}\right)^{+}$.

Two hundred theoretical structures were generated for both $\left(8 \mathrm{dG}+2 \mathrm{NH}_{4}\right)^{2+}$ and $\left(12 \mathrm{dG}+3 \mathrm{NH}_{4}\right)^{3+}$ in a quadruplex arrangement to see if aggregation was occurring. The scatter plot obtained for $(8 \mathrm{dG}+$ $\left.2 \mathrm{NH}_{4}\right)^{2+}$ indicated that both a globular and G-quadruplex family of structures were present in which the G-quadruplex $\left(378 \AA^{2}\right)$ is $10 \mathrm{kcal} / \mathrm{mol}$ lower in energy than the globular structures $\left(400 \AA^{2}\right)$. When $(12 \mathrm{dG}+$ $\left.3 \mathrm{NH}_{4}\right)^{3+}$ was analyzed, only one family of structures was observed in its scatter plot corresponding to a quadruplex structure with a cross section of $449 \AA^{2}$. No globular structures were found in the scatter plot for $\left(12 \mathrm{dG}+3 \mathrm{NH}_{4}\right)^{3+}$, suggesting that once three G-quartets stack they become very stable and do not want to convert to a globular form. However, in order to determine if the $\left(12 \mathrm{dG}+3 \mathrm{NH}_{4}\right)^{3+}$ was really occurring as a quadruplex, $12 \mathrm{dGs}$ and $3 \mathrm{NH}_{4}{ }^{+}$were placed in a random orientation and 200 structures were acquired from $600 \mathrm{~K}$ simulated annealing. From this starting structure, only one family of structures in a globular conformation was observed. The globular family has an energy $25 \mathrm{kcal} / \mathrm{mol}$ higher than the quadruplex struc-

Table 1. Experimental and theoretical collision cross sections $\left(\AA^{2}\right)$ of the dG clusters Theory $^{\text {b }}$

\begin{tabular}{lccc} 
dG Cluster & Expt $^{\mathrm{a}}$ & Quadruplex & Globular \\
\hline \hline Nominal $\left(4 \mathrm{dG}+\mathrm{NH}_{4}\right)^{+}$peak & & & \\
$\left(4 \mathrm{dG}+\mathrm{NH}_{4}\right)^{+}$ & 288 & 291 & 227 \\
$\left(8 \mathrm{dG}+2 \mathrm{NH}_{4}\right)^{2+}$ & 372 & 378 & 400 \\
$\left(12 \mathrm{dG}+3 \mathrm{NH}_{4}\right)^{3+}$ & 450 & 449 & 436 \\
Nominal $\left(6 \mathrm{dG}+\mathrm{NH}_{4}\right)^{+}$peak & & & \\
$\left(6 \mathrm{dG}+\mathrm{NH}_{4}\right)^{+}$ & 296 & $360^{\mathrm{c}}$ & 295 \\
$\left(12 \mathrm{dG}+2 \mathrm{NH}_{4}\right)^{2+}$ & 452 & 450 & 432 \\
$\left(18 \mathrm{dG}+3 \mathrm{NH}_{4}\right)^{3+}$ & 579 & 583 & 602 \\
$\left(24 \mathrm{dG}+4 \mathrm{NH}_{4}\right)^{4+}$ & 692 & 695 & 671 \\
Nominal $\left(11 \mathrm{dG}+2 \mathrm{NH}_{4}\right)^{2+}$ & & & \\
peak & & & \\
$\left(11 \mathrm{dG}+2 \mathrm{NH}_{4}\right)^{2+}$ & 440 & 442 & 421 \\
$\left(22 \mathrm{dG}+4 \mathrm{NH}_{4}\right)^{4+}$ & 682 & 680 & 658 \\
Others & & & \\
$\left(14 \mathrm{dG}+3 \mathrm{NH}_{4}\right)^{3+}$ & 513 & 511 & 492 \\
$\left(16 \mathrm{dG}+3 \mathrm{NH}_{4}\right)^{3+}$ & 539 & 543 & 517 \\
$\left(17 \mathrm{dG}+3 \mathrm{NH}_{4}\right)^{3+}$ & 572 & 575 & 595 \\
$\left(23 \mathrm{dG}+4 \mathrm{NH}_{4}\right)^{4+}$ & 690 & 687 & 662 \\
\hline
\end{tabular}

${ }^{\mathrm{a}} 1 \%$ reproducibility error.

${ }^{b}$ Globular cross sections are averages of the lowest $5-10 \mathrm{kcal} / \mathrm{mol}$ structures where dGs are arranged randomly in the starting structure; cross sections of the quadruplexes are averages of the lowest 5-10 $\mathrm{kcal} / \mathrm{mol}$ structures when the starting structure for the dGs are in quadruplex arrangement (see text) $\leq 2 \%$ standard deviation.

cThe cross section for the quadruplex form of $\left(6 \mathrm{dG}+\mathrm{NH}_{4}\right)^{+}$was taken from the starting structure as it quickly converted to a globular form. 
a)

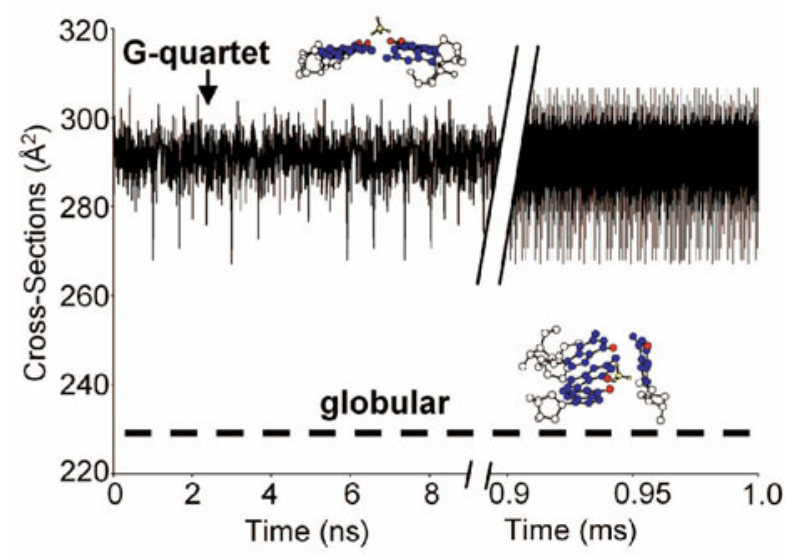

b)

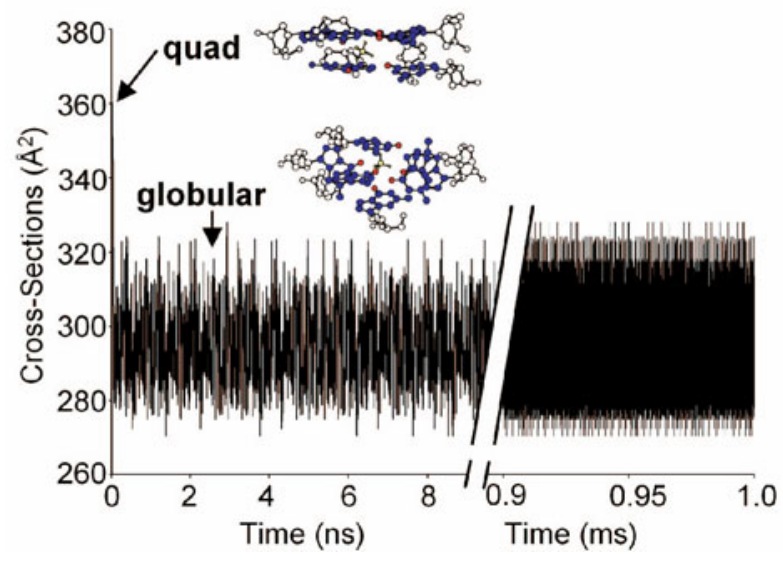

Figure 5. $300 \mathrm{~K}$ molecular dynamics simulations for (a) $(4 \mathrm{dG}+$ $\left.\mathrm{NH}_{4}\right)^{+}$and $(\mathbf{b})\left(6 \mathrm{dG}+\mathrm{NH}_{4}\right)^{+}$starting in a quadruplex arrangement. One ms of dynamics were run. There is no change in structure during the break from $10 \mathrm{~ns}$ to $0.9 \mathrm{~ms}$ in either dynamics run. $\left(4 \mathrm{dG}+\mathrm{NH}_{4}\right)^{+}$retains a quadruplex structure for the whole ms of dynamics, while $\left(6 \mathrm{dG}+\mathrm{NH}_{4}\right)^{+}$falls into a globular structure after only a few picoseconds and remains globular.

tures (which occurred when the starting structure was a quadruplex) and a cross section $13 \AA^{2}$ smaller (Table 1). No conformers corresponding to a quadruplex structure occur when the starting structure is not a quadruplex.

Originally, a +1 charge was used to calculate the experimental cross sections corresponding to $(4 \mathrm{dG}+$ $\left.\mathrm{NH}_{4}\right)^{+}$. However, if aggregation is occurring, the peaks at 610 and $700 \mu$ s will not have a +1 charge. Cross section is directly proportional to charge (eq 2), so the shortest time peak at $610 \mu$ s may not actually be $150 \AA^{2}$ as calculated for $\left(4 \mathrm{dG}+\mathrm{NH}_{4}\right)^{+}$, but may instead correspond to $300 \AA^{2}$ for $\left(8 \mathrm{dG}+2 \mathrm{NH}_{4}\right)^{2+}$ or $450 \AA^{2}$ for $\left(12 \mathrm{dG}+3 \mathrm{NH}_{4}\right)^{3+}$. Neither the globular or quadruplex conformation of $\left(8 \mathrm{dG}+2 \mathrm{NH}_{4}\right)^{2+}$ match the experimental +2 cross section, and the globular structure for $\left(12 \mathrm{dG}+3 \mathrm{NH}_{4}\right)^{3+}$ does not agree within $2 \%$ of the +3 cross section. However, the quadruplex structure of $\left(12 \mathrm{dG}+3 \mathrm{NH}_{4}\right)^{3+}$ does agree within $2 \%$ of the +3 cross section, allowing the shortest time peak to be assigned to the quadruplex conformation of $\left(12 \mathrm{dG}+3 \mathrm{NH}_{4}\right)^{3+}$. Similarly, a cross section of $372 \AA^{2}$ is obtained for the $700 \mu \mathrm{s}$ peak [assuming it corresponds to (8dG + $\left.2 \mathrm{NH}_{4}\right)^{2+}$ ] and this value is in good agreement with the cross section obtained for the quadruplex structure of $\left(8 \mathrm{dG}+2 \mathrm{NH}_{4}\right)^{2+}$. All of the quadruplex structures are illustrated in Figure 4.

By identifying all of the ATD peaks corresponding to the nominal mass of $\left(4 \mathrm{dG}+\mathrm{NH}_{4}\right)^{+}$, the injection energy dependence can be explained. At low injection energy, most of the sample is $\left(12 \mathrm{dG}+3 \mathrm{NH}_{4}\right)^{3+}$ and $(8 \mathrm{dG}+$ $\left.2 \mathrm{NH}_{4}\right)^{2+}$. However, as the injection energy is raised, $\left(12 \mathrm{dG}+3 \mathrm{NH}_{4}\right)^{3+}$ is broken into $\left(8 \mathrm{dG}+2 \mathrm{NH}_{4}\right)^{2+}$ and $\left(4 \mathrm{dG}+\mathrm{NH}_{4}\right)^{+}$, explaining the increase in $(4 \mathrm{dG}+$ $\left.\mathrm{NH}_{4}\right)^{+}$and decrease in $\left(12 \mathrm{dG}+3 \mathrm{NH}_{4}\right)^{3+}$. This result indicates that the lowest injection energy is probably the closest to solution conditions, since the largest clusters can be broken at the higher injection energies. Thus, only low injection energy ATDs are shown for the rest of the clusters observed.

After assigning the ATDs, it was found that none of the peaks observed agrees with the globular forms of $\left(4 \mathrm{dG}+\mathrm{NH}_{4}\right)^{+},\left(8 \mathrm{dG}+2 \mathrm{NH}_{4}\right)^{2+}$, or $\left(12 \mathrm{dG}+3 \mathrm{NH}_{4}\right)^{3+}$. This observation brought forth an interesting question because the globular form of $\left(4 \mathrm{dG}+\mathrm{NH}_{4}\right)^{+}$is lower in energy than the G-quartet, but did not occur in the experiment. To test the stability of the quadruplex form of $\left(4 \mathrm{dG}+\mathrm{NH}_{4}\right)^{+}, 300 \mathrm{~K}$ molecular dynamics simulation were performed, instead of the $600 \mathrm{~K}$ simulated annealing cycle. The dynamics were run for $1 \mathrm{~ms}$ and every 5 ps a structure was saved and its cross section calculated. In the dynamics simulations, $\left(4 \mathrm{dG}+\mathrm{NH}_{4}\right)^{+}$remains in the quadruplex structure for the whole ms, indicating that it is a very stable structure and not easily converted to the globular form (except when heated as in the annealing protocol). The dynamics run is given in Figure $5 \mathrm{a}$, where no change in structure is observed between the break at $10 \mathrm{~ns}$ and $0.9 \mathrm{~ms}$. Since the globular conformation of $\left(4 \mathrm{dG}+\mathrm{NH}_{4}\right)^{+}$is predicted to be lower in energy than the G-quartet, it appears that

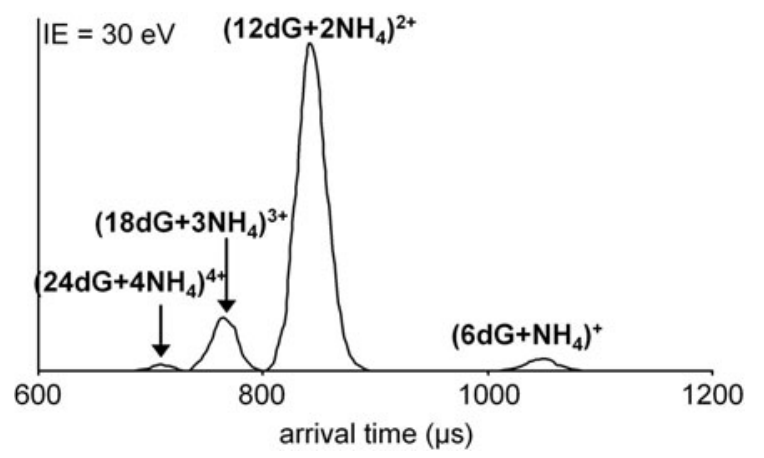

Figure 6. The ATD for $\left(6 \mathrm{dG}+\mathrm{NH}_{4}\right)^{+}$at $\mathrm{IE}=30 \mathrm{eV}$. The four peaks are assigned to $\left(6 \mathrm{dG}+\mathrm{NH}_{4}\right)^{+},\left(12 \mathrm{dG}+2 \mathrm{NH}_{4}\right)^{2+},(18 \mathrm{dG}+$ $\left.3 \mathrm{NH}_{4}\right)^{3+}$, and $\left(24 \mathrm{dG}+4 \mathrm{NH}_{4}\right)^{4+}$ by comparing the experimental and theoretical cross sections. 


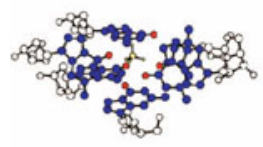

$\left(6 \mathrm{dG}+\mathrm{NH}_{4}\right)^{+}$

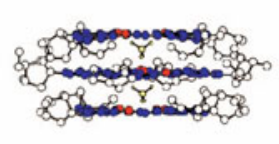

$\left(12 \mathrm{dG}+2 \mathrm{NH}_{4}\right)^{2+}$

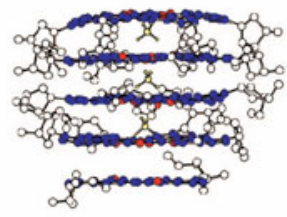

$\left(18 \mathrm{dG}+3 \mathrm{NH}_{4}\right)^{3+}$

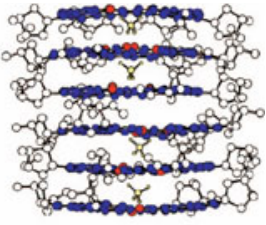

$\left(24 \mathrm{dG}+4 \mathrm{NH}_{4}\right)^{4+}$

Figure 7. Theoretical structures for $\left(6 \mathrm{dG}+\mathrm{NH}_{4}\right)^{+},\left(12 \mathrm{dG}+2 \mathrm{NH}_{4}\right)^{2+},\left(18 \mathrm{dG}+3 \mathrm{NH}_{4}\right)^{3+}$, and $(24 \mathrm{dG}$ $\left.+4 \mathrm{NH}_{4}\right)^{4+} ;\left(6 \mathrm{dG}+\mathrm{NH}_{4}\right)^{+}$is the only cluster which does not have a quadruplex structure. The guanine oxygen atom is red, guanines are blue, ammonium is yellow, and sugars are shown in white (hydrogen atoms on each $\mathrm{dG}$ have been omitted for clarity).

quadruplexes are present in solution and survive the ESI process and subsequent dehydration intact. If quadruplexes were not present in the solution, a globular structure should have been observed for $\left(4 \mathrm{dG}+\mathrm{NH}_{4}\right)^{+}$.

$\left(6 d G+\mathrm{NH}_{4}\right)^{+}$. The ATD for $\left(6 \mathrm{dG}+\mathrm{NH}_{4}\right)^{+}$is shown in Figure 6 at an injection energy of $30 \mathrm{eV}$. Four peaks are observed in the ATD with cross sections of 173, 193, 226, and $296 \AA^{2}$ (calculated for a +1 ion). Theoretical modeling was performed in order to determine the structure associated with each ATD peak. Due to the aggregation present in the $\left(4 \mathrm{dG}+\mathrm{NH}_{4}\right)^{+}$system, three higher order clusters including $\left(12 \mathrm{dG}+2 \mathrm{NH}_{4}\right)^{2+}$, $\left(18 \mathrm{dG}+3 \mathrm{NH}_{4}\right)^{3+}$, and $\left(24 \mathrm{dG}+4 \mathrm{NH}_{4}\right)^{4+}$, all with the same $m / z$ as $\left(6 \mathrm{dG}+\mathrm{NH}_{4}\right)^{+}$, were evaluated.

Both randomly arranged and G-quadruplex structures were used as the starting structures for $(6 \mathrm{dG}+$ $\left.\mathrm{NH}_{4}\right)^{+},\left(12 \mathrm{dG}+2 \mathrm{NH}_{4}\right)^{2+},\left(18 \mathrm{dG}+3 \mathrm{NH}_{4}\right)^{3+}$, and $\left(24 \mathrm{dG}+4 \mathrm{NH}_{4}\right)^{4+}$ in the $600 \mathrm{~K}$ simulated annealing protocol. Upon analysis of the cross section versus energy scatter plots for $\left(6 \mathrm{dG}+\mathrm{NH}_{4}\right)^{+}$, only one family of structures with a cross section of $295 \AA^{2}$ was observed for both the G-quadruplex and randomly arranged starting structures. In both cases, the only family of structures which were observed correspond to dGs arranged in a globular formation around the $\mathrm{NH}_{4}{ }^{+}$ion (Figure 7). The cross section of this globular structure agrees within $2 \%$ of the experimental value for the ATD peak at $1050 \mu \mathrm{s}$ (Table 1). The starting structure of (6dG $\left.+\mathrm{NH}_{4}\right)^{+}$in a quadruplex arrangement appeared to be very unstable as it did not survive one minimization in the annealing protocol before it converted to a globular structure. The instability of $\left(6 \mathrm{dG}+\mathrm{NH}_{4}\right)^{+}$became apparent in the $300 \mathrm{~K}$ molecular dynamics simulations. In the dynamics simulation, the quadruplex form of $\left(6 \mathrm{dG}+\mathrm{NH}_{4}\right)^{+}$converted to the globular form after just a few picoseconds, indicating that it was not stable in a quadruplex arrangement and explaining why it was not observed in the experiment (see Figure $5 b$ ).

The theoretical structures obtained for (6dG + $\left.\mathrm{NH}_{4}\right)^{+}$only allowed assignment of the longest time peak, and the earlier time peaks could not be accounted for. Based on the fact that aggregates are observed for the nominal $\left(4 \mathrm{dG}+\mathrm{NH}_{4}\right)^{+}$feature, the experimental cross sections for the three shortest time peaks were recalculated for $+4,+3$, and +2 clusters, giving values of 692,579 , and $452 \AA^{2}$. To compare these cross sections with theory, the scatter plots of energy versus cross section for $\left(12 \mathrm{dG}+2 \mathrm{NH}_{4}\right)^{2+},\left(18 \mathrm{dG}+3 \mathrm{NH}_{4}\right)^{3+}$, and $\left(24 \mathrm{dG}+4 \mathrm{NH}_{4}\right)^{4+}$ were examined. When the dGs were randomly arranged in the starting structures for $(12 \mathrm{dG}$ $\left.+2 \mathrm{NH}_{4}\right)^{2+},\left(18 \mathrm{dG}+3 \mathrm{NH}_{4}\right)^{3+}$, and $\left(24 \mathrm{dG}+4 \mathrm{NH}_{4}\right)^{4+}$, only one family of structures in a globular conformation resulted. However, in all cases the globular structures did not match any of the experimental cross sections (Table 1). When a G-quadruplex starting structure was used, only one family of structures in a G-quadruplex orientation resulted, and in all cases the G-quadruplex structure was at least $20 \mathrm{kcal} / \mathrm{mol}$ lower in energy than the corresponding globular structure. The average cross sections for each are reported in Table 1. After analysis of all the cross sections for the clusters, the peaks in the ATD in Figure 6 could be assigned. The peak at $700 \mu \mathrm{s}$ agreed with the cross section for the $\left(24 \mathrm{dG}+4 \mathrm{NH}_{4}\right)^{4+}$ quadruplex, the peak at $770 \mu$ s matched the quadruplex structure for $\left(18 \mathrm{dG}+\mathrm{NH}_{4}\right)^{3+}$, the $\left(12 \mathrm{dG}+2 \mathrm{NH}_{4}\right)^{2+}$ quadruplex structure was assigned to the peak at 850 $\mu \mathrm{s}$, and the globular structure for $\left(6 \mathrm{dG}+\mathrm{NH}_{4}\right)^{+}$ correlated with the peak at $1050 \mu$ s. The quadruplex structures for $\left(12 \mathrm{dG}+2 \mathrm{NH}_{4}\right)^{2+},\left(18 \mathrm{dG}+3 \mathrm{NH}_{4}\right)^{3+}$, and $\left(24 \mathrm{dG}+4 \mathrm{NH}_{4}\right)^{4+}$ are all shown in Figure 7. The (12dG $\left.+2 \mathrm{NH}_{4}\right)^{2+}$ quadruplex structure has three G-quartets stacked on top of each other with an $\mathrm{NH}_{4}{ }^{+}$ion between each layer. Four G-quartets stack in the $(18 \mathrm{dG}+$ $\left.3 \mathrm{NH}_{4}\right)^{3+}$ quadruplex, while the two extra dGs assemble directly below the quartets. $\left(24 \mathrm{dG}+4 \mathrm{NH}_{4}\right)^{4+}$ has 6 layers of G-quartets stacked on top of each other and the 4 ammonium ions sit between the two top and bottom layers, leaving two G-quartets in the middle of the cluster to stack without any cation stabilization.

$\left(11 \mathrm{dG}+2 \mathrm{NH}_{4}\right)^{2+}$. A typical ATD for $(11 \mathrm{dG}+$ $\left.2 \mathrm{NH}_{4}\right)^{2+}$ is shown in Figure 8 at an injection energy of $30 \mathrm{eV}$. Two peaks are observed in the ATD with cross sections of 341 and $440 \AA^{2}$ (assuming a +2 charge state). Due to the presence of higher order clusters in the nominal $\left(4 \mathrm{dG}+\mathrm{NH}_{4}\right)^{+}$and $\left(6 \mathrm{dG}+\mathrm{NH}_{4}\right)^{+}$peaks, randomly arranged and quadruplex structures of both $\left(11 \mathrm{dG}+2 \mathrm{NH}_{4}\right)^{2+}$ and $\left(22 \mathrm{dG}+4 \mathrm{NH}_{4}\right)^{4+}$ were modeled to compare to the experimental values obtained from the ATD peaks.

Three hundred low-energy structures were gener- 


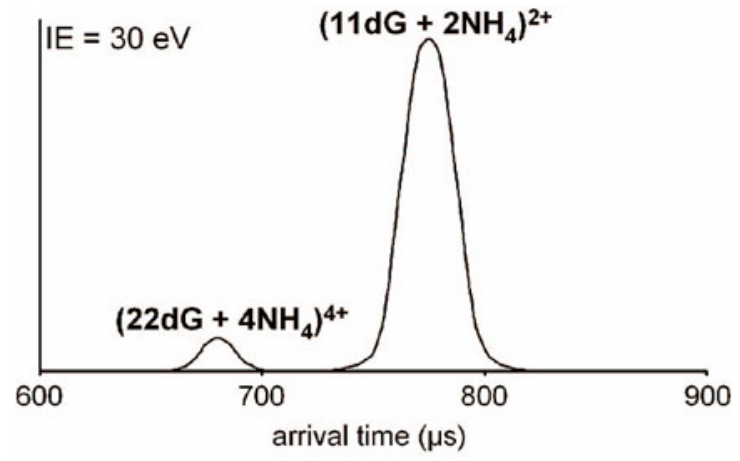

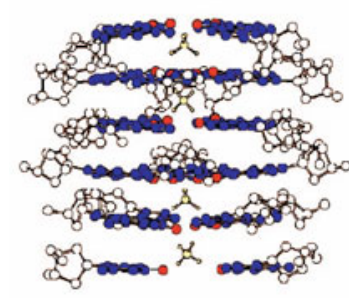

$\left(22 \mathrm{dG}+4 \mathrm{NH}_{4}\right)^{4+}$

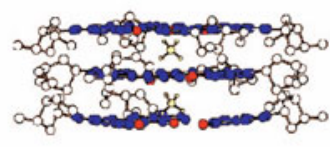

$\left(11 \mathrm{dG}+2 \mathrm{NH}_{4}\right)^{2+}$
Figure 8. The ATD for $\left(11 \mathrm{dG}+2 \mathrm{NH}_{4}\right)^{2+}$ at $\mathrm{IE}=30 \mathrm{eV}$. The two ATD peaks are assigned to quadruplex structures for (11dG + $\left.2 \mathrm{NH}_{4}\right)^{2+}$ and $\left(22 \mathrm{dG}+4 \mathrm{NH}_{4}\right)^{4+}$. The theoretical structures which correspond to the experimental cross sections are shown below the ATD. The guanine oxygen atom is red, guanines are blue, ammonium is yellow, and sugars are shown in white (hydrogen atoms on each dG have been omitted for clarity).

ated for both $\left(11 \mathrm{dG}+2 \mathrm{NH}_{4}\right)^{2+}$ and $\left(22 \mathrm{dG}+4 \mathrm{NH}_{4}\right)^{4+}$. Only one family of structures was observed for the randomly arranged starting structures of $(11 \mathrm{dG}+$ $\left.2 \mathrm{NH}_{4}\right)^{2+}$ and $\left(22 \mathrm{dG}+4 \mathrm{NH}_{4}\right)^{4+}$ corresponding to globular structures. However, the globular cross sections did not match any of the experimental cross sections. When a quadruplex structure was used as the starting structure, only one family of structures corresponding to a quadruplex family was observed in the scatter plots (average cross section reported in Table 1). The cross section of the quadruplex structures for $(11 \mathrm{dG}+$ $\left.2 \mathrm{NH}_{4}\right)^{2+}$ and $\left(22 \mathrm{dG}+4 \mathrm{NH}_{4}\right)^{4+}$ agree with the experimental values, allowing the quadruplex structure of $\left(22 \mathrm{dG}+4 \mathrm{NH}_{4}\right)^{4+}$ to be assigned to the shortest time peak and the quadruplex structure of $\left(11 \mathrm{dG}+2 \mathrm{NH}_{4}\right)^{2+}$ to be assigned to the longest time peak. The quadruplexes for $\left(11 \mathrm{dG}+2 \mathrm{NH}_{4}\right)^{2+}$ and $\left(22 \mathrm{dG}+4 \mathrm{NH}_{4}\right)^{4+}$ are shown in Figure 8. The $\left(11 \mathrm{dG}+2 \mathrm{NH}_{4}\right)^{2+}$ quadruplex has two G-quartets stacked on top of each other, while the three remaining $\mathrm{dGs}$ assemble below the G-quartets, and an $\mathrm{NH}_{4}{ }^{+}$coordinates between each layer. Five G-quartets stack in the $\left(22 \mathrm{dG}+4 \mathrm{NH}_{4}\right)^{4+}$ quadruplex and the two extra dGs stack directly below the quartets.

14, 16, and $17 \mathrm{dGs}$ with $3 \mathrm{NH}_{4}^{+}$and $23 \mathrm{dGs}$ with 4 $\mathrm{NH}_{4}{ }^{+}$. An ATD for $\left(16 \mathrm{dG}+3 \mathrm{NH}_{4}\right)^{3+}$ is shown in Figure 9. Only a single peak is detected and similar ATDs are observed for 14 and $17 \mathrm{dGs}$ with $3 \mathrm{NH}_{4}{ }^{+}$, and $23 \mathrm{dGs}$ with $4 \mathrm{NH}_{4}{ }^{+}$(see Table 1 for experimental and theoretical cross sections). A single peak in the ATD suggests that these systems do not have aggregates and each has only one structure. Theoretical modeling was again performed on randomly arranged dGs and a quadruplex arrangement of each cluster. When scatter plots for the randomly arranged dGs were analyzed, in each case only one family of structures was observed. As with the other clusters examined, these families correspond to globular structures, and the cross sections do not correlate with the experimental cross sections (Table 1). When quadruplexes were used as starting structure of each cluster, only one family of structures corresponding to G-quadruplexes was observed. The quadruplex structures determined from theoretical calculations where all lower in energy than the globular structures and all matched the experimental cross sections measured from the ATDs within 1-2\% (Table 1). Figure 10 illustrates the theoretical structures of these four clusters. As with the quadruplex structures shown in the other clusters, G-quartets stack on top of each other and if too few dGs are present to finish a quartet, they just sit below the stacked quartets, with the exception of $\left(17 \mathrm{dG}+3 \mathrm{NH}_{4}\right)^{3+}$, where the extra $\mathrm{dG}$ prefers to coordinate to the side of the quadruplex.

\section{Summary}

Mass spectrometry, ion mobility, and molecular mechanics/dynamics results presented in this paper provide several important insights into the gas-phase conformations of G-quadruplexes. The primary observations are given below.

1. dG clusters readily with ammonium ions and complexes from $\left(4 \mathrm{dG}+\mathrm{NH}_{4}\right)^{+}$to $\left(24 \mathrm{dG}+4 \mathrm{NH}_{4}\right)^{4+}$ are observed using both mass spectrometry and ion mobility.

2. Quadruplex structures are exclusively observed for all $\mathrm{dG}$ clusters in the presence of ammonium ion except $\left(6 \mathrm{dG}+\mathrm{NH}_{4}\right)^{+}$, which has a globular structure.

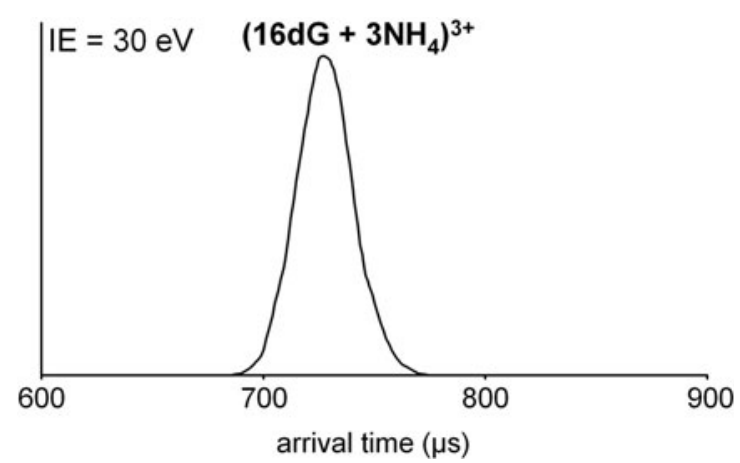

Figure 9. Single peak ATDs are observed for complexes where 14,16 , and $17 \mathrm{dGs}$ cluster with $3 \mathrm{NH}_{4}{ }^{+}$, and $23 \mathrm{dGs}$ cluster with 4 $\mathrm{NH}_{4}{ }^{+}$, indicating that only one structure is present for each complex. The ATD shown is for $\left(16 \mathrm{dG}+3 \mathrm{NH}_{4}\right)^{3+}$. 


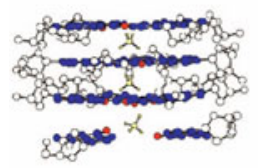

$\left(14 \mathrm{dG}+3 \mathrm{NH}_{4}\right)^{3+}$

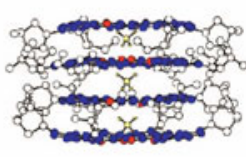

$\left(16 \mathrm{dG}+3 \mathrm{NH}_{4}\right)^{3+}$

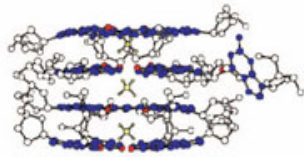

$\left(17 \mathrm{dG}+3 \mathrm{NH}_{4}\right)^{3+}$

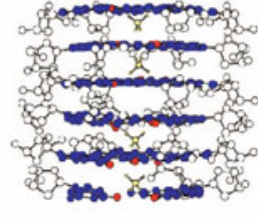

$\left(23 \mathrm{dG}+4 \mathrm{NH}_{4}\right)^{4+}$

Figure 10. Theoretical structures for $\left(14 \mathrm{dG}+3 \mathrm{NH}_{4}\right)^{3+},\left(16 \mathrm{dG}+3 \mathrm{NH}_{4}\right)^{3+},\left(17 \mathrm{dG}+3 \mathrm{NH}_{4}\right)^{3+}$, and $\left(23 \mathrm{dG}+4 \mathrm{NH}_{4}\right)^{4+}$. Guanine oxygen atoms are red, guanines are blue, ammonium is yellow, and sugars are shown in white (hydrogen atoms on each dG have been omitted for clarity).

3. If the number of dGs is not a multiple of four, then at least two G-quartets must stack to provide sufficient stability for a quadruplex structure to result. $\left(6 \mathrm{dG}+\mathrm{NH}_{4}\right)^{+}$is not stable in a quadruplex structure and forms a globular structure readily. In the case of $\left(11 \mathrm{dG}+2 \mathrm{NH}_{4}\right)^{2+}$, where two G-quartets stack, a quadruplex structure is retained in which the excess dGs assemble below the quartets.

4. The G-quartet structure of $\left(4 \mathrm{dG}+\mathrm{NH}_{4}\right)^{+}$is not the lowest energy structure predicted by AMBER calculations, but it is very stable as shown from $1 \mathrm{~ms}$ of $300 \mathrm{~K}$ molecular dynamic simulations. Since the G-quartet form of $\left(4 \mathrm{dG}+\mathrm{NH}_{4}\right)^{+}$is the only conformation observed experimentally (the lowest-energy globular structure is not observed), it appears that solution phase quadruplexes are retained in the absence of solvent following the spray/evaporation process.

\section{Acknowledgments}

The authors gratefully acknowledge the support of the National Science Foundation under grant CHE-0140215. The authors would also like to thank Dr. Catherine J. Carpenter for all her hard work on the cover illustration.

\section{References}

1. Sinden, R. R. DNA Structure and Function; Academic Press: San Diego, CA, 1994.

2. Singleton, C. K. J. Biol. Chem. 1983, 258, 7661.

3. Sullivan, K. M.; Lilley, D. M. J. Mol. Biol. 1987, 193, 397.

4. Neidle, S.; Read, M. A. Biopolymers 2001, 56, 195.

5. Lyonnais, S.; Hounsou, C.; Teulade-Fichou, M.; Jeusset, J.; Cam, E. L.; Mirambeau, G. Nucleic Acid Res. 2002, 30, 5276.

6. Singleton, C. K.; Klysik, J.; Stirdivant, S. M.; Wells, R. D. Nature (London) 1982, 299, 312.

7. Singleton, C. K.; Klysik, J.; Wells, R. D. Proc. Natl. Acad. Sci. U.S.A. 1983, 80, 2447.

8. Sen, D.; Gilbert, W. Nature 1988, 334, 364.

9. Evans, T.; Schon, E.; Gora-Maslak, G.; Patterson, J.; Efstratiadis, A. Nucleic Acid Res. 1984, 12, 8043.

10. Sarig, G. J. Biol. Chem. 1997, 272, 4474.

11. Blackburn, E. H. Cell 1994, 77, 621

12. Hurley, L. H.; Wheelhouse, R. T.; Sun, D.; Kerwin, S. M.; Salazar, M.; Fedoroff, O. Y.; Han, F. X.; Han, H. Y.; Izbicka, E.; Von Hoff, D. D. Pharmacol. Ther. 2000, 85, 141.

13. Han, H. Y.; Hurley, L. H. Trends Pharmacol. Sci. 2000, 21, 136.

14. Fenn, J. B.; Mann, M.; Meng, C. K.; Wong, S. F.; Whitehouse, C. M. Science 1989, 246, 64.

15. Smith, R. D.; Loo, J. A.; Edmonds, C. G.; Barinaga, H. R.; Udseth, H. R. Anal. Chem. 1990, 62, 882.
16. Chait, B.; Kent, S. B. H. Science 1992, 257, 1885.

17. Whitehouse, C. M.; Dreyer, R. N.; Yamashita, M.; Fenn, J. B. Anal. Chem. 1985, 57, 675.

18. Yamashita, M.; Fenn, J. B. J. Phys. Chem. 1984, 88, 2240.

19. Henry, K. D.; Williams, E. R.; Wang, B.-H.; McLafferty, F. W.; Shabanowitz, J.; Hunt, D. F. Proc. Natl. Acad. Sci. U.S.A. 1989, $86,9075$.

20. Henry, K. D.; Quinn, J. P.; McLafferty, F. W. J. Am. Chem. Soc. 1991, 113, 5447.

21. Chowdhury, S. K.; Eshraghi, J.; Wolfe, H.; Forde, D.; Hlavac, A. G.; Johnston, D. Anal. Chem. 1995, 67, 390.

22. Fukushima, K.; Iwahashi, H. Chem. Commun. 2000, 11, 895.

23. Manet, I.; Francini, L.; Masiero, S.; Pieraccini, S.; Spada, G. P.; Gottarelli, G. Helv. Chim. Acta 2001, 84, 2096.

24. Aggerholm, T.; Nanita, S. C.; Koch, K. J.; Cooks, R. G. J. Mass Spectrom. 2003, 38, 87.

25. Goodlett, D. R.; Camp, D. G., II; Hardin, C. C.; Corregan, M; Smith, R. D. Biol. Mass Spectrom. 1993, 22, 181.

26. Rosu, F.; Gabelica, V.; Houssier, C.; Colson, P.; De Pauw, E. Rapid Commun. Mass Spectrom. 2002, 16, 1729.

27. Bowers, M. T.; Kemper, P. R.; von Helden, G.; van Koppen, P. A. M. Science 1993, 260, 1446.

28. Clemmer, D. E.; Jarrold, M. F. Mass Spectrom. Rev. 1997, 32, 577.

29. Wyttenbach, T.; Kempe, P. R.; Bowers, M. T. Int. J. Mass Spectrom. 2001, 212, 13.

30. Mason, E. A.; McDaniel, E. W. Transport Properties of Ions in Gases; Wiley: New York, 1988.

31. Hyperchem 7.0; Hypercube Inc., Gainesville, FL, 2002.

32. Case, D. A.; Pearlman, D. A.; Caldwell, J. W.; Cheatham, T. E., III; Wang, J.; Ross, W. S.; Simmerling, C. L.; Darden, T. A.; Merz, K. M.; Stanton, R. V.; Cheng, A. L.; Vincent, J. J.; Crowley, M.; Tsui, V.; Gohlke, H.; Radmer, R. J.; Duan, Y.; Pitera, J.; Massova, I.; Seibel, G. L.; Singh, U. C.; Weiner, P. K.; Kollman, P. A. AMBER 7 2002; University of California, San Francisco.

33. Gidden, J.; Ferzoco, A.; Baker, E. S.; Bowers, M. T. J. Am. Chem. Soc. 2004, 126, 15132

34. Gidden, J.; Bowers, M. T. J. Phys. Chem. B 2003, 107, 12829.

35. Baker, E. S.; Gidden, J.; Ferzoco, A.; Bowers, M. T. Phys. Chem. Chem. Phys. 2004, 6, 2786.

36. Wyttenbach, T.; von Helden, G.; Batka, J. J.; Carlat, D.; Bowers, M. T. J. Am. Soc. Mass Spectrom. 1997, 8, 275.

37. Wyttenbach, T.; Witt, M.; Bowers, M. T. J. Am. Chem. Soc. 2000, 122, 3458.

38. Mesleh, M. F.; Hunter, J. M.; Shvartsburg, A. A.; Schwartz, G. C.; Jarrold, M. F. J. Phys. Chem. 1996, 100, 16082.

39. Shvartsburg, A. A.; Jarrold, M. F. Chem. Phys. Lett. 1996, 261, 86.

40. Wyttenbach, T.; Bowers, M. T. Top. Curr. Chem. 2003, 225, 207.

41. Bernstein, S. L.; Wyttenbach, T.; Baumketner, A.; Shea, J.-E.; Bitan, G.; Teplow, D. B.; Bowers, M. T. J. Am. Chem. Soc. 2005, 127, 2075. 